\title{
EKSISTENSI PESANTREN DALAM PENGEMBANGAN PENDIDIKAN ISLAM DI INDONESIA
}

\author{
Muh. Aidil Sudarmono \\ Pascasarjana Doktoral UIN Alauddin Makassar \\ sudarmono.aidil@yahoo.com
}

\begin{abstract}
Abstrak
Pesantren merupakan sarana pendidikan di Indonesia yang saat ini diakui sebagai lembaga pendidikan resmi walaupun sistem akreditasinya tidak diterbitkan. Hal ini disebabkan karena pesantren umumnya berdiri atas kurikulum mandiri, bukan berdasarkan kurikulum yang diterapkan oleh pemerintah melalui undang-undang sistem pendidikan Nasional di Indonesia. Pesantren bukanlah hal yang baru dalam sistem pendidikan di Indonesia. Sejarah telah mencatat bahwa pesantren di Indonesia telah tumbuh dan berkembang bahkan sejak abad ke-16 atau berkisar tahun 1700-an. Banyak tokoh yang memiliki peran besar dalam perkembangan pesantren di Indonesia, antara lain K.H. Hasyim As'ari, K.H. Ahmad Dahlan, K.H. Zaenal Mustofa, K.H.M. Ilyas Ruhiyat, K.H. Ali Ma'shum, Sayyid Sulaiman, Kyai Itsbat, Syaikh Musthafa Husein Nasution, KH Ahmad Sahal, KH Zainuddin Fananie, dan KH Imam Zarkasy, dan lain-lain. Kebanyakan mereka adalah pendiri dan pimpinan pesantren, meskipun untuk K.H. Ahmad Dahlan, beliau tidak memiliki pesantren tetapi pemikiran dan organisasinya mampu melahirkan banyak pesantren di Indonesia.
\end{abstract}

Kata Kunci: Pesantren, Sejarah, Pendidikan Islam

\section{PENDAHULUAN}

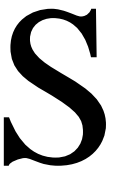

ulit dipungkiri bahwa sebelum kemerdekaan terjadi persaingan antara segi ideologi, cita-cita bahkan segi politis dan fisik.Pemerintah kolonial Hindia Belanda senantiasa mencurigai eksistensi pesantren sehingga mereka selalu campur tangan terhadap pendidikan pesantren. Hal ini tampak jelas dengan pendirian Priesterreden (Pengadilan Agama) pada tahun 1882 oleh Belanda dengan tujuan mengawasi pendidikan pesantren. (Hasbullah, 1982). Bukan hanya pengadilan agama yang didirikan Belanda untuk memantau kegiatan pesantren. Bahkan pada saat itu, pesantren dihantam pula oleh lahirnya ide-ide pembaharuan barat yang merasuk ke dunia pesantren sehingga terjadi stagnasi pendidikan pesantren akibat dari budaya barat 
yang terus merajalela.Hal ini ditandai dengan terjadinya pemberontakan dan kehancuran-kehancuran yang mengakibatkan berhentinya kegiatan perkembangan ilmu pengetahuan dan kebudayaan dunia Islam. Di zaman pra kemerdekaan kondisi pondok pesantren pernah mencapai titik kritis sebagai lembaga pendidikan tradisional. Islam yang diajarkan dalam pondok disinyalir telah mengalami teror dan intimidasi oleh musuh Islam.Sehingga saat itu pendidikan pesantren mengalami tantangan yang begitu berat.Namun demikian karena pesantren merupakan penjelmaan kepribadian bangsa sehingga eksistensinya dapat kembali berdiri tegak meskipun badai senantiasa menggerogoti. Kajian ini penting dilakukan untuk mendapatkan deskripsi dan analisis tentang ciri khas, perkembangan, dan tokoh pondok pesantren di Indonesia sehingga pembaca mendapatkan gambaran utuh tentang eksistensi dan peran pondok pesantren sebagai salah satu soko guru pendidikan di Indonesia.

\section{Pengertian dan Ciri Khas Pesantren}

Menurut Haidar Putra Daulay (2007: 63), istilah pesantren berasal dari kata santri dengan awalan pe dan akhiran an yang berarti tempat tinggal santri. Pendapat senda diungkapkan oleh Soegarda (1976: 233) yang menyatakan bahwa pesantren asal katanya adalah santri, yaitu seorang yang belajar agama Islam sehingga dengan demikian pesantren mempunyai arti tempat orang berkumpul untuk belajar agama Islam. Ziemek dalam Soegrda juga menyebutkan bahwa asal etimologi dari pesantren adalah pesantrian berarti tempat santri.Santri atau murid umumnya sangat berbeda-beda mendapat pelajaran dari pemimpin pesantren (kyai) dan oleh para guru atau ulama (ustaz). Pelajaran mencakup berbagai bidang tentang pengetahuan Islam. Dari beberapa pendapat di atas maka dapat ditarik kesimpulan bahwa pesantren adalah sekumpulan orang yang tinggal dalam sebuah lembaga pendidikan yang di dalamnya ditekankan dan lebih terkhusus untuk mengkaji pengetahuan agama Islam. Ketika berbicara tentang pesantren tentu tidak serta merta melainkan mempunyai ciri-ciri terkhusus. Haidar Putra Daulay (2007) juga menjelaskan bahwa ciri atau unsur pokok tentang pesantren digolongkan menjadi lima yaitu pondok, masjid, santri, kyai, 
dan pengajian kitab-kitab kuning.Untuk melihat lebih rinci mengenai maslaah karakteristik pesnatren maka dapat dilihat pada tabel di bawah ini.

\section{Pondok}

Istilah pondok berasal dari bahasa Arab Funduq yang berarti hotel dan tempat bermalam.Istilah pondok diartikan juga sebagai asrama. Dengan demikian pondok mengandung makna sebagai tempat tinggal.Sebuah pesantren mesti memiliki asrama tempat tinggal santri dan kyai. Di tempat tersebut selalu terjadi komunikasi antara santri dan kyai. Di pondok, seorang santri maupun santriwati patuh dan taat terhadap peraturan-peraturan yang diadakan ada kegiatan pada waktu tertentu yang mesti dilaksanakan oleh santri.Ada waktu belajar, shalat, makan, tidur, istirahat, dan sebagainya bahkan ada juga waktu untuk jaga malam. (Yunus, 1973: 324). Ada beberapa alasan pokok sebaba pentingnya pondok dalam sebuah pesantren yaitu:

a. Banyaknya santri dan santriwati berdatangan dari daerah yang jauh untuk menuntut ilmu kepada seorang kyai yang sudah termashur keahliannya.

b. Pesantren-pesantren tersebut terletak di desa-desa dimana tidak tersedia perumahan untuk menampung santri dan santriwati yang berdatangan dari luar daerah.

c. Ada sikap timbal balik antara kyai dan santri dimana para santri dan santriwati menganggap bahwa kyai adalah seolah-olah orang tuanya sendiri. (Dhofier, 1984: 46).

\section{Masjid}

Masjid diartikan secara harfiah adalah tempat sujud karena ditempat ini setidak-tidaknya seorang muslim lima kali sehari semalam melaksanakan shalat. Fungsi masjid tidak hanya untuk shalat tetapi juga mempunyai fungsi lain seperti pendidikan dan lain sebagainya. Pada zaman Rasulullah saw masjid berfungsi sebagai tempat ibadah dan urusan-urusan sosial kemasyarakatan serta pendidikan.Suatu pesantren mutlak harus memiliki masjid, sebab disitulah akan dilangsungkan proses pendidikan dalam bentuk komunikasi belajar mengajar antara kyai dan santri. Masjid sebagai pusat pendidikan Islam telah berlangsung 
sejak masa Rasulullah saw, dilanjutkan oleh khulafa al-Rasyidin, Dinasti Bani Umayyah, Abbasiyah, Fathimiyah, dan dinasti-dinasti lain. Tradisi itu tetap dipegang oleh para kyai pemimpin pesantren untuk menjadikan masjid sebagai pusat pendidikan. Kendatipun pada saat sekarang pesantren telah memiliki local belajar yang banyak untuk tempat berlangsungnya proses belajar mengajar, namun masjid difungsikan sebaai tempat belajar.

\section{Santri}

Santri adalah siswa yang belajar di pesantren. Santri ini digolongkan menjadi dua kelompok yaitu:

a. Santri mukmim, yaitu santri yang berdatangan dari tempattempat yang jauh yang tidak memungkinkan dia untuk pulang kerumahnya maka dia mondok atau tinggal di pesantren. Sebagai santri mukmim mereka memiliki kewajiban-kewajiban tertentu.

b. Santri kalong, yaitu siswa-siswa yang berasal dari daerah sekitar yang memungkinkan mereka pulan ketempat kediaman masingmasing. Santri ini mengikuti tempat pelajaran dengan cara pulang pergi antara rumahnya dengan pesantren.

Pada pesantren yang masih tergolong tradisional lamanya santri bermukim ditempat itu bukan ditentukan oleh ukuran tahun atau kelas, tetapi diukur dari kitab yang dibaca.Seperti yang diungkapkan terdahulu bahwa kitab-kitab itu ada yang bersifat dasar, menengah, dan besar.Kitab-kitab itu juga semakin tinggi semakin sulit memahami isinya.Oleh karena itu dituntut penguasaan kitab-kitab dasar dan menengah sebelum memasuki kitab-kitab besar.

\section{Kyai}

Kyai adalah tokoh sentral dalam suatu pesantren.Maju mundurnya suatu pesantren ditentukan oleh wibawa dan charisma oleh kyai. Menurut asal usulnya perkataan kyai dalam bahasa Jawa dipakai untuk tiga jenis gelar yang saling berbeda, yaitu: 
a. Sebagai gelar kehormatan bagi barang-barang yang dianggap keramat umpamanya "kyai garuda kencana" dipakai untuk sebutan kereta emas yang ada di keratin Yogyakarta.

b. Gelar kehormatan untuk orang-orang tua pada umumnya

c. Gelar yang diberikan oleh masyarakat kepada seseorang ahli agama Islam yang memiliki pesantren dan mengajarkan kitabkitab Islam klasik pada santri. (Dhofier, 1984: 50).

Kyai dalam pembahasan ini adalah mengacu pada orang-orang yang ketiga.Kendatipun bahwa gelar kyai saat ini tidak hanya diperuntuhkan bagi yangmemiliki pesantren.Sudah banyak juga gelar kyai digunakan terhadap ulama yang tidak memiliki pesantren.Istilah ulama kadang juga digunakan istilah lain seperti Buya di Sumatera Barat, Tengku di Aceh, Ajengan di Jawa Barat, dan kyai di Jawa Tengah dan Jawa Timur.

\section{Pengajian Kitab-Kitab Islam Klasik}

Kitab-kitab Islam klasik yang lebih popular dengan sebutan kitab kuning.Kitab-kitab ini ditulis oleh ulama-ulama Islam pada zaman pertengahan.Kepintaran dan kemahiran seorang santri diukur dari kemampuannya membaca, serta mensyarahkan (menjelaskan) isi kitabkitab tersebut. Untuk tahu membaca sebuah kitab dengan benar seorang santri dituntut untuk mahir dalam ilmu-ilmu bantu seperti nahu, syaraf, balaghah, dan ma'ani bayan. Kriteria kemampuan membaca dan mensyarahkan kitab bukan saja merupakan keriteria diterima atau tidak seorang sebagai ulama atau kyai pada zaman dahulu saja, tetapi juga sampai saat sekarang.Salah satu persyaratan seseorang telah meemnuhi keriteria sebagai ulama atau kyai adalah kemampuannya membaca serta menjelaskan isi kitab-kitab tersebut. Kitab-kitab klasik yang diajarkan dipesantren dapat digolongkan delapan kelompok yaitu, nahu/syaraf, fikih, ushul fikih, hadis, tafsir, tauhid, tasawwuf dan etika, serta cabangcabang ilmu lainnya seperti tarikh dan balaghah. Pada umumnya kitabkitab itu dapat pula digolongkan dari tingkatannya yakni ada tingkatan dasar, menengah, dan ada kitab-kitab besar. (Dhofier, 1984: 55). 
Tinjuan Periodik Tahapan Perkembangan Pondok Pesantren di Indonesia

Masuknya era 70 an pesantren mengalami perubahan cukup signifikan dan menakjubkan baik diwilayah perdesaan, pinggiran kota, maupun perkotaan. Pesantre mulai berbenah diri dengan melakukan berbagai inovasi untuk pengembangan sistem pendidikan baik oleh masyarakat maupun pemerintah.Dalam aspek kurikulum yaitu dengan masuknya penegtahuan umum dan keterampilan ke dalam pesantren adalah sebagai upaya memberikan bekal tambahan agar para santri bila telah menyelesaikan pendidikannya dapat hidup layak dalam masyarakat.

\section{Periode Sebelum Kemerdekaan Indonesia}

Periode sebelum kemerdekaan adalah zaman penjajahan yakni ketika pemerintah kolonial Belanda berada di Indonesia.Pada zaman ini, pendidikan di lembaga pesantren cukup mendapat kontrol ketat oleh Belanda. Hal ini dilakukan untuk menghambat proses pendidikan khususnya pendidikan Islam. Hal ini karena pesantren merupakan satusatunya lembaga pendidikan Islam. Memang pada masa penjajahan, pondok pesantren menjadi satu-satunya lembaga pendidikan Islam yang menggembleng kader-kader umat yang tangguh dan gigih menentang penjajahan. Dalam pondok pesantren sebelum kemerdekaan tertanam patriotisme dan fanatisme agama yang begitu kuat. Oleh karena itu wajar kalau pemerintah kolonial Belanda yang saat itu masih menjajah bangsa Indonesia senantiasa menghalangi perkembangan pondok pesantren. (Muzayyin Arifin, 2003: 230).

Perkembangan pesantren itu sendiri sebelum kemerdekaan bukan hanya ditakuti tetapi berusaha dihalang-halangi oleh pemerintah kolonial Belanda.Sehingga pesantren harus bersaing dengan sekolah-sekolah yang didirikan oleh Belanda dengan tetap eksis dan bahkan bertambah jumlahnya.Pada awal abad ke-19 jumlah pesantren untuk jawa sebanyak 1.853 buah dengan jumlah santri 16.556 orang.Dan menjelang akhir abad ke-19 jumlah pesantren sudah mencapai 14.929 buah dengan jumlah santri sebanyak 222.663 orang. Diantara nama-nama pesantren 
yang terkenal seperti: Pondok Pesantren Gontor, Ponorogo, Pondok Pesantren Musthafawiyah, Purbabaru, Pondok Pesantren Cipasung, Jawa Barat, Pondok Pesantren As Shiddiqiyyah, Jember, Pondok Pesantren Tebu Ireng, Jombang, Pondok Pesantren Al Munawwir, Krapyak, Yogyakarta, dan masih banyak lagi yang tidak mungkin penulis dapat cantumkan semuanya. (Hasbullah, 2001: 149).

Peningkatan jumlah pondok pesantren beserta jumlah santri sebagaimana kutipan di atas merupakan indikasi bahwa pesantren adalah lembaga pendidikan Islam yang terus berkembang meskipun pelan tapi pasti. Pesantren meskipun terbatas ruang geraknya namun tetap berkembang di tengah penguasa Belanda yang terus memberikan tekanan.Tekanan yang diterima pesantren pada masa penjajahan tidak mengurangi semangat perkembangannya.Pesantren justru bertahan terus dan tetap tegap berdiri. Perannya sangat tampak melalui kader-kadernya dan tokoh-tokoh perjuangan nasional yang lahir dari pesantren.Tokohtokoh nasional yang lahir dari lingkungan pesantren terus berjuang dalam bingkai agama Islam dengan mempertahankan ideologi, politik dan cita-cita dengan rela mengorbankan jiwa raga demi persaingan. Semua ini terjadi pada zaman pra kemerdekaan.Di antara tokoh agama sekaligus tokoh nasional yang berjuang dalam bingkai Islam adalah $\mathrm{KH}$. Hayim Ashari, KH. Ahmad Dahlan, KH. Ahmad Siddiq, dan bahkan Ir, Sukarno yang merupakan presiden pertama Indonesia adalah jebolan pesantren.

\section{Periode Setelah Kemerdekaan Indonesia}

Pada awal kemerdekaan bangsa Indonesia, perdebatan dan diskusi panjang mengenai sistem pendidikan nasional yang tepat untuk diterapkan di Indonesia, pondok pesantren sebagai lembaga pendidikan yang telah berdiri di berbagai daerah "digadang-gadang" sebagai alternatif sistem pendidikan nasional, meskipun akhirnya gagal. Namun demikian melalui Badan Pekerja Komite Nasional Indonesia Pusat (BPKNIP) pada tanggal 22 Desember 1945 mengeluarkan maklumat yang substansinya pengakuan terhadap eksistensi pondok pesantren yang berisi: "dalam memajukan pendidikan dan pengajaran sekurang- 
kurangnya diusahakan agar pengajaran di langgar, surau, masjid dan madrasah berjalan terus dan ditingkatkan”. Kemudian hanya dalam jangka lima hari setelah lahirnya maklumat tertanggal 22 Desember 1945 itu, maka pada tangal 27 Desember 1945 BPKNIP kembali mengeluarkan maklumat yang isinya antara lain (butir 5) menyarankan : "karena madrasah dan pondok pesantren pada hakikatnya adalah salah satu alat dan sumber pendidikan dan pencerdasan rakyat jelata yang sudah berakar dalam masyarakat Indonesia pada umumnya, hendaklah pula mendapat perhatian dan bantuan yang nyata berupa tuntunan dan bantuan materiil dari pemerintah". Kedua Maklumat BPKNIP di atas jelas memiliki implikasi yang sangat besar terhadap kemajuan pondok pesantren, maka wajarlah jika maklumat itu dijadikan tonggak sejarah kebangkitan pondok pesantren secara legal formal dalam sistem pendidikan nasional di Indonesia. (Depag Agama RI, 2014)

Pesantren tampil dengan bentuk yang baru namun tetap mempertahankan hal-hal mendasar pada dirinya agar tidak tergilas oleh perkembangan modernisasi. Pesantren diharapkan terbuka terhadap dunia namun tetap menyediakan filter agar nilai dasarnya tidak luntur. Sifat fleksibilitasnya senantiasa harus tetap dipertahankan, karena kehadirannya adalah cerminan bangsa Indonesia. Kehadiran pesantren dengan sifatnya yang fleksibel ternyata terbukti pada awal kemerdekaan terus menyesuaikan diri dengan perkembangan saat itu. Pesantren pada awal kemerdekaan terus merenovasi sistem sehingga dikenal istilah pesantren modern agar dapat mengisi kemerdekaan ini dengan sebaikbaiknya. Pesantren modern ini ditandai dengan Pesantren mulai akrab dengan metodologi ilmiah modern, Berorientasi pada pendidikan dan fungsional, Diversifikasi program dan semakin terbuka, dan Berfungsi sebagai pengembangan masyarakat. (Hasbullah, 2001: 155).

Kutipan di atas setidaknya memberikan gambaran bahwa pondok pesantren melakukan modernisasi serta senantiasa membenahi diri untuk mengisi kemerdekaan.Pesantren sebagai lembaga pendidikan Islam terus berusaha aktif dalam pembangunan sebagai bukti kemampuannya dalam pembangunan sumber daya manusia yang berkualitas. Pada zaman sesudah kemerdekaan perkembangan pesantren cukup signifikan karena 
pemerintah telah memberikan perhatian yang serius terhadap lembaga ini. Perhatian ini didasari oleh kesadaran bahwa pesantren adalah induk pendidikan Islam yang banyak memberikan peran serta dalam merebut kemerdekaan sehingga eksistensinya dalam mengisi kemerdekaan ini tidak diragukan lagi. Pada zaman ini pesantren terus membenahi diri sehingga peran serta di masyarakat tetap dirasakan. Dengan demikian disimpulkan bahwa dalam era kemerdekaan pesantren senantiasa aktif dalam mengisi kemerdekaan dengan melakukan beberapa pembenahan dalam sistem pendidikannya.Pesantren membenahi diri agar dapat terus berguna bagi kehidupan sosial dan kemasyarakatan.

\section{Periode Perkembangan Pesantren Modern di Indonesia}

Pondok pesantren modern adalah pesantren yang berusaha mengintegrasikan secara penuh sistem klasikal dan sekolah ke dalam pondok. Pengajian kitab-kitab klasik tetap ada tetapi tidak lagi menonjol bahkan ada yang cuma menjadi pelengkap dan berubah menjadi mata pelajaran seperti Pondok Pesantren Modern Gontor, Pondok Pesantren Modern Jombang, Pondok Pesantren Modern Al-Zaitun, dan sebagainya. (Hasbullah, 2001: 157). Hal ini merupakan usaha pembaharuan yang dilakukan oleh pondok pesantren agar dapat tetap eksis dalam era modernisasi. Usaha-usaha pembaharuan pesantren tradisional menuju pesantren modern dilaksanakan dengan pembenahan sistem yang relevan. Usaha-usaha pembaharuan sistem pendidikan dan pengajaran di pondok pesantren khususnya pesantren modern biasanya ditandai dengan beberapa hal yakni sebagai berikut: 1) Mengubah kurikulum yang orientasinya sesuai kebutuhan masyarakat, 2) Peningkatan mutu guru dan prasarana, 3) Melakukan pembaharuan secara bertahap, 4) Kyai seyogyanya selaku pemilik pesantren terbuka dalam usaha pembaharuan yang positif. (Ridwan Nasir, 2005: 102).

Oleh karena itu, dalam rangka menjaga kelangsungan hidup pesantren, pemerintah memberikan bimbingan dan bantuan serta motivasi agar pesantren berkembang sesuai dengan tuntutan kebutuhan masyarakat dan pembangunan.Pesantren modern agak berbeda dengan pesantren tradisional yang mempertahankan sistem pengajaran kitab 
klasik. Namun pesantren modern cenderung untuk meningkatkan mutu penyelenggaraan pendidikan dengan pembenahan beberapa hal yang sifatnya tidak mendasar. Meskipun demikian nilai dasar yang ditanamkan dalam pesantren tetap dipegang teguh, seperti: 1) Kemampuan dalam menciptakan sebuah sikap hidup universal yang merata, 2) Hidup mandiri, dan 3) Sikap tidak menggantungkan diri kepada siapa dan lembaga masyarakat apapun. (Hasbullah, 2001: 159).

Nilai dasar tersebut di atas jangan sampai luntur oleh kemajuan peradaban.Ia harus senantiasa dipertahankan. Seiring dengan perkembangan zaman, trend baru pun perlu ada dalam lingkungan pesantren. Pada masa Orde Baru, peran pemerintah dalam pengembangan dan pembinaan madrasah dan pondok pesantren diakui positif dan konstruktif, khususnya dalam dua dekade terakhir 1980-an 1990-an, pemerintah melalui Departemen Agama melalui Proyek Pembangunan Lima Tahun (Pelita). Sejak Pelita I hingga Pelita VI mengeluarkan dana pembinaan untuk pondok pesantren diperoleh dari berbagai instansi terkait, dari tingkat pemerintah pusat maupun daerah. Walaupun dana tersebut dirasakan masih sangat kurang bagi pengembangan pondok pesantren ke depan.

Bukan hanya sampai di situ, dinamika pondok pesantren di era pemerintahan Orde Baru ini terus mengalami pembaharuan dan modernisasi, baik secara kelembagaan maupun kurikulumnya, banyak pondok pesantren yang membuka pendidikan formal dengan menerapkan kurikulum sekolah umum, sehingga dalam mengoperasionalkan kegiatan pembelajaran mereka berafiliasi dengan Departemen Pendidikan dan Kebudayaan, sedangkan kegiatan pembelajaran 'kitab kuning' sebagai ciri khas kepesantrenan tetap berkoordinasi dengan Dep. Agama. Model pondok pesantren inilah yang kemudian lebih dikenal dengan istilah “pesantren modern'.Bahkan, madrasah yang dibina oleh pondok pesantren juga banyak yang menyesuaikan diri dengan pola madrasah (non-pesantren) yang berdasarkan Surat Keputusan Bersama (SKB) yaitu Menteri Agama, Menteri Pendidikan dan Kebudayaan, dan Menteri Dalam Negeri pada tahun 1975 yang diistilahkan 'SKB Tiga Menteri' tentang "Peningkatan Mutu Pendidikan pada Madrasah". Dalam SKB itu 
ditetapkan bahwa mata pelajaran umum di madrasah sekurangkurangnya harus $70 \%$ dari seluruh muatan kurikulum, sedangkan pendidikan agama tinggal 30\%. Dengan alasan prosentase tersebut, ada yang berpendapat bahwa kurikulum yang ditetapkan pemerintah tersebut telah terjadi "bias" yang tidak sesuai lagi dengan jiwa dan tujuan pondok pesantren. Akibatnya ada beberapa madrasah di pondok pesantren yang mengambil kebijakan untuk menetapkan kurikulumnya sendiri, misalnya Pondok Modern Gontor Ponorogo.Pada 21 Mei 1998, kedigdayaan pemerintahan Orde Baru di bawah kekuasaan Presiden Soeharto lengser dan memasuki era reformasi, pergumulan pondok pesantren di Indonesia mendapat pengakuan secara legal formal dan memiliki posisi sangat kuat sebagai lembaga pendidikan keagamaan. Karena berkat paradigma reformasi, demokratisasi dan keadilan dalam dunia pendidikan serta perjuangan para ulama, tokoh agama, pakar pendidikan Islam dan dukungan umat Islam, akhirnya secara konstitusional dan legal formal, pondok pesantren mendapat pengakuan secara nasional sekaligus memiliki landasan formal dengan dimasukkannya kata "pesantren" sebagai bentuk pendidikan keagamaan.

Dalam Undang-Undang Republik Indonesia Nomor 20 Tahun 2003 tentang Sistem Pendidikan Nasional, pasal 30 ayat 4 berbunyi : "Pendidikan keagamaan berbentuk pendidikan diniyah, pesantren, pasraman, pabhaja samanera, dan bentuk lain yang sejenis”. Dengan dimasukkannya pondok pesantren dalam sistem pendidikan nasional itu, secara legal formal pondok pesantren memiliki hak dan kewajiban yang sama dengan lembaga pendidikan lainnya dalam rangka operasionalisasi program pencerdasan kehidupan bangsa dan peningkatan kualitas sumber daya manusia (SDM) melalui proses pembelajaran di pondok pesantren. Sebelum Undang Undang 20 Tahun 2003 itu disahkan oleh DPR, ternyata Kementerian Agama telah terlebih dahulu melakukan langkah politis dan strategis yakni melakukan restrukturisasi organisasi Kementerian Agama mulai dari pusat hingga daerah. Dalam Keputusan Menteri Agama (KMA) Nomor 75 Tahun 1984 tentang Susunan Organisasi dan Tata Kerja Departemen Agama (Pusat) ditetapkan bahwa pejabat yang menangani pembinaan dan pengembangan pondok 
pesantren menjadi tugas pokok dan fungsi Sub Direktorat (Subdit) Madrasah Diniyah dan Pondok Pesantren pada Direktorat Perguruan Agama Islam Kementerian Agama. Dengan kondisi yang demikian berarti pondok pesanten yang jumlahnya puluhan ribu hanya ditangani oleh pejabat eselon III.

Dengan demikian, sebagai responsitas terhadap tuntutan reformasi, khususnya mengenai 'keadilan' dalam upaya peningkatan dan pengembangan mutu pendidikan, maka melalui pertimbangan 'tuntutan reformasi' keberadaan KMA Nomor 75 Tahun 1984 yang telah berlaku selama 16 tahun dilakukan penyempurnaan dan restrukturisasi organisasi dengan ditetapkannya Keputusan Menteri Agama Nomor 1 Tahun 2000 tentang Struktur Organisasi dan Tata Kerja Departemen Agama. Dalam KMA nomor 1 Tahun 2000 itu ditetapkan bahwa pejabat yang menangani pembinaan dan pengembangan pondok pesantren menjadi tugas pokok dan fungsi Direktorat Pendidikan Keagamaan dan Pondok Pesantren. Ini berarti pejabat yang menangani pembinaan dan pengembangan pondok pesantren di Indonesia mengalami kemajuan yang sangat strategis karena langsung ditangani oleh pejabat eselon II.Perubahan nomenklatur tentang pondok pesantren dalam jajaran Kementerian Agama ini secara otomatis juga terjadi pada tingkat Kantor Wilayah Kementerian Agama Provinsi dan Kantor Kementerian Agama Kabupaten/Kota.

\section{Para Tokoh pendiri dan Pengembangan Pesantren di Indonesia}

Pesantren merupakan pendidikan di Indonesia yang saat ini diakui sebagai lembaga pendidikan sarana resmi walaupun sistem akreditasinya tidak diterbitkan.Hal ini disebabkan karena pesantren umumnya berdiri atas kurikulum mandiri, bukan berdasarkan kurikulum yang diterapkan oleh pemerintah melalui undang-undang sistem pendidikan Nasional di Indonesia. Pesantren bukanlah hal yang baru dalam sistem pendidikan di Indonesia. Sejarah telah mencatat bahwa pesantren di Indonesia telah tumbuh dan berkembang bahkan sejak abad ke-16 atau berkisar tahun 1700-an. (Imam Syafei, 2003: 3). Banyak tokoh yang memiliki peran besar dalam perkembangan pesantren di Indonesia, antara lain K.H. 
Hasyim As'ari, K.H. Ahmad Dahlan, K.H. Zaenal Mustofa, K.H.M. Ilyas Ruhiyat, K.H. Ali Ma'shum, Sayyid Sulaiman, Kyai Itsbat, Syaikh Musthafa Husein Nasution, KH Ahmad Sahal, KH Zainuddin Fananie, dan KH Imam Zarkasy, dan lain-lain. Kebanyakan mereka adalah pendiri dan pimpinan pesantren, meskipun untuk K.H. Ahmad Dahlan, beliau tidak memiliki pesantren tetapi pemikiran dan organisasinya mampu melahirkan banyak pesantren di Indonesia.

Salah satunya adalah Sayyid Sulaiman yang merupakan pendiri Pesantren Sidogiri yang berada di Pasuruan.Terdapat dua versi mengenai tahun berdirinya. Ada yang mengatakan berdiri pada tahun $1718 \mathrm{M}$. Namun ada juga yang mengklaim bahwa pesantren Sidogiri didirikan sekitar tahun $1745 \mathrm{M}$. Terlepas dari dua versi tersebut, yang pasti adalah keberadaan pesantren di Indonesia memang sudah menjadi sejarah yang lama. Sayyid Sulaiman adalah keturunan Rasulullah dari marga Basyaiban. Ayahnya, Sayyid Abdurrahman, adalah seorang perantau dari negeri wali, Tarim Hadramaut Yaman. Sedangkan ibunya, Syarifah Khodijah, adalah putri Sultan Hasanuddin bin Sunan Gunung Jati. Dengan demikian, dari garis ibu, Sayyid Sulaiman merupakan cucu Sunan Gunung Jati. (Dhofier, 1982: 148). Kemudian K.H. Hasyim Asy'ari mendirikan Pesantren Tebuireng yang dikenal karena figur pendirinya sosok ulama kharismatik pencetus organisasi Nahdlatul Ulama (NU) pada 1926 yang dilanjutkan oleh putranya KH Wahid Hasyim yang menjadi Menteri Agama pertama Republik Indonesia sedang cucunya yang bernama KH Abdurrahman "Gus Dur" Wahid menjadi presiden keempat RI dan yang pertama berasal dari kalangan santri.

K.H. Itsbat mendirikan LPI Darul Ulum Banyuanyar Pamekasan Madura atau lebih dikenal dengan Pondok Banyuanyar adalah termasuk dari 5 pesantren tertua di Indonesia.Didirikan pada 1787 dan pesantren ini berkembang dengan pesat sampai sekarang.Di Madura khususnya kabupaten Pamekasan, pesantren Banyuanyar memiliki pengaruh yang tidak kecil.Sistem pendidikan di pesantren ini menganut sistem kombinasi salaf dan modern. Penguasaan kitab kuning tetap dipelihara dan pendidikan formal yang sesuai kurikulum pemerintah juga diadakan 
untuk memenuhi tantangan dan tuntutan zaman. Oleh karena itu, tidak heran banyak alumni pesantren ini yang sudah menjadi tokoh berpengaruh. (Abdurrahman Wahid, 1989: 95). Kemudian, di tahun berikutnya, pesantren pun tumbuh dan berkembang meluas hingga ke daerah Jawa tengah, Jawa barat.Di Jawa Tengah ada Pondok Pesantren Jamsaren berkisar Tahun 1750. Kemudian 1768 ponpes MiftahuL Huda Jawa Timur, kemudian Pondok Pesantren Buntet Jawa Barat pada 1785, dan Pondok Pesantren Darul Ulum Banyu Anyar tahun 1787 di Madura. Beralih ke Pulau Sumatera, di sana ada pondok pesantren AlMusthafawiyah atau yang lebih akrab dikenal dengan sebutan Pesantren Purba Baru Mandailing Natal. Pesantren ini didirikan sekitar tahun 1912 M oleh Syaikh Musthafa Husein Nasution. Pondok Gontor didirikan pada 10 April 1926 di Ponorogo, Jawa Timur oleh tiga bersaudara putra Kiai Santoso Anom Besari.Tiga bersaudara ini adalah KH Ahmad Sahal, KH Zainuddin Fananie, dan KH Imam Zarkasy yang kemudian dikenal dengan istilah Trimurti. (Hasbullah, 2001: 187).

\section{SIMPULAN}

Pesantren adalah sekumpulan orang yang tinggal dalam sebuah lembaga pendidikan yang di dalamnya ditekankan dan lebih terkhusus untuk mengkaji pengetahuan agama Islam. Ciri atau unsur pokok tentang pesantren digolongkan menjadi lima yaitu pondok, masjid, santri, kyai, dan pengajian kitab-kitab kuning. Dalam Undang-Undang Republik Indonesia Nomor 20 Tahun 2003 tentang Sistem Pendidikan Nasional, pasal 30 ayat 4 berbunyi: "Pendidikan keagamaan berbentuk pendidikan diniyah, pesantren, pasraman, pabhaja samanera, dan bentuk lain yang sejenis". Dengan dimasukkannya pondok pesantren dalam sistem pendidikan nasional itu, secara legal formal pondok pesantren memiliki hak dan kewajiban yang sama dengan lembaga pendidikan lainnya dalam rangka operasionalisasi program pencerdasan kehidupan bangsa dan peningkatan kualitas sumber daya manusia (SDM) melalui proses pembelajaran di pondok pesantren. Adapun Tokoh-tokoh pelopor perekmbangan pesantren di Indonesia anatara lain; K.H. Hasyim As'ari, K.H. Ahmad Dahlan, K.H. Zaenal Mustofa, K.H.M. Ilyas Ruhiyat, K.H. 
Ali Ma'shum, Sayyid Sulaiman, Kyai Itsbat, Syaikh Musthafa Husein Nasution, KH Ahmad Sahal, KH Zainuddin Fananie, dan KH Imam Zarkasy.

\section{DAFTAR PUSTAKA}

Arifin, Muzayyin. 2003. Kapita Selekta Pendidikan Islam,.Jakarta: Bumi Aksara.

Departemen Agama, 2004. Grand Desain Pendidikan Keagamaan dan Pondok Pesantren. Jakarta: Direktorat Peka Pontren pada Ditjen Bagais Dep. Agama,.

Dewan Redaksi, 1994. Ensiklopedi Islam, jilid IV. Jakarta: Ichtiar Van Hoeve.

Dhofier, Zamakhsyari. 1982. Tradisi Pesantren: Studi Tentang Pandangan Hidup Kyai. Jakarta: LP3ES.

Hasbullah. Sejarah Pendidikan Islam di Indonesia Lintasan Sejarah Pertumbuhan

Nasir, Ridwan. 2005. Mencari Tipologi Format Pendidikan Ideal Pondok Pesantren di Tengah Arus Perubahan.Cet. I; Yogyakarta: Pustaka Pelajar.

Putra, Daulay Haidar. 2007. Sejarah Pertumbuhan dan Pembaharuan Pendidikan Islam di Indonesia,.Jakarta: Kencana.

Soegarda. 1976. Pendidikan Dalam Alam Indonesia Merdeka.Jakarta: Gunug Agung.

Syafei Imam, dkk. 2013. Pesantren yang Terus Bertumbuh Pesat dalam Tabloid Pesantren Edisi 2.

Wahid, Abdurrahman. 1989. Bunga Rampai Pesantren. Jakarta: Dharma Bakti. 
